\title{
A NEW SPECIES \\ IN THE HIERACIUM LYCOPIFOLIUM AGG. (ASTERACEAE) FROM THE WESTERN CARPATHIANS
}

\author{
ZBIGNIEW SZELĄG \\ Institute of Botany, Jagiellonian University \\ Kopernika 31, 31-501 Kraków, Poland \\ e-mail: azszelag@wp.pl
}

(Received: March 11, 2010. Accepted: May 24, 2010)

\begin{abstract}
Hieracium zajacii Szeląg is described from the Velká Fatra Mts in Slovakia. It is the first representative of $H$. lycopifolium agg. to be found in the Carpathians. The new species is tetraploid $(2 n=36)$ and reproduces apomictically. Its origin is briefly discussed.
\end{abstract}

KEY WORDS: Asteraceae, chromosome number, distribution, Hieracium, mode of reproduction, new species, Velká Fatra Mts.

\section{INTRODUCTION}

The Western Carpathians are characterized by a rich and diverse flora of the genus Hieracium L. Especially interesting are the mountain ranges situated south of the Tatra Mts, i.e. south of the main chain of the Western Carpathians, where the glacial refugia of the mountain Hieracia were probably situated (Szelagg 2004). I have been carrying out research on this territory for several years now, which has resulted in discovery of two Hieracium species in the Nízke Tatry Mts new to the Carpathians (Szeląg 2006a; Ronikier and Szeląg 2008).

The present paper is a result of field studies in the Velká Fatra Mts. When exploring the upper part of the Turecká Dolina valley, situated on the southern slope of Mt. Krížna, I discovered a taxon belonging to the H. lycopifolium agg. (= H. lycopifolium s. lat., sensu Zahn 1938). The main distinguishing features of $H$. lycopifolium agg. taxa are the soft, hairy, conspicuously dentate, amplexicaul cauline leaves and the stem covered by numerous to subdense simple hairs. The geographical range of the H. lycopifolium agg. comprises the western Alps, centred on the Alpes Maritimes. Isolated stations are known from the Vosgeses, the Jura, southern Schwarzwald and Schwabien (Zahn 1938), as well as in the Abruzzi where it was recently found by Gottschlich (2009). No taxon of the H. lycopifolium agg. has been reported from the Carpathians to date.

\section{MATERIAL AND METHODS}

All plants for karyological analysis and cultivation in the garden were raised from the seeds collected on 2 August 2008 in the Turecká Dolina valley in the Velká Fatra Mts at ca. $900 \mathrm{~m}$ a.s.l. Detailed information on the experimental methods and karyological procedures followed here are given in Mráz and Szeląg (2004), Szeląg (2006b) and Szelagg et al. (2007), but briefly the mode of reproduction was determined by excision experiments in the garden-cultivated plants, and the chromosomes were counted by Tomasz Ilnicki on three plants. The description of the new species is based on six herbarium specimens collected in the Velká Fatra Mts in August 2008.

\section{RESULTS}

After comparison of the plants collected in the Velká Fatra Mts with herbarium specimens of $H$. lycopifolium Froel. from Baden-Württemberg, Germany, including specimens from the locus classicus in Karlsruhe, I concluded that the Carpathian plants differed from H. lycopifolium in several important features. The production of fruit in six flower heads in which the anthers had been excised showed that plants from the Velká Fatra Mts reproduced apomictically. It was also found that plants from the Velká Fatra Mts were tetraploid $(2 \mathrm{n}=36)$, like H. lycopifolium from 


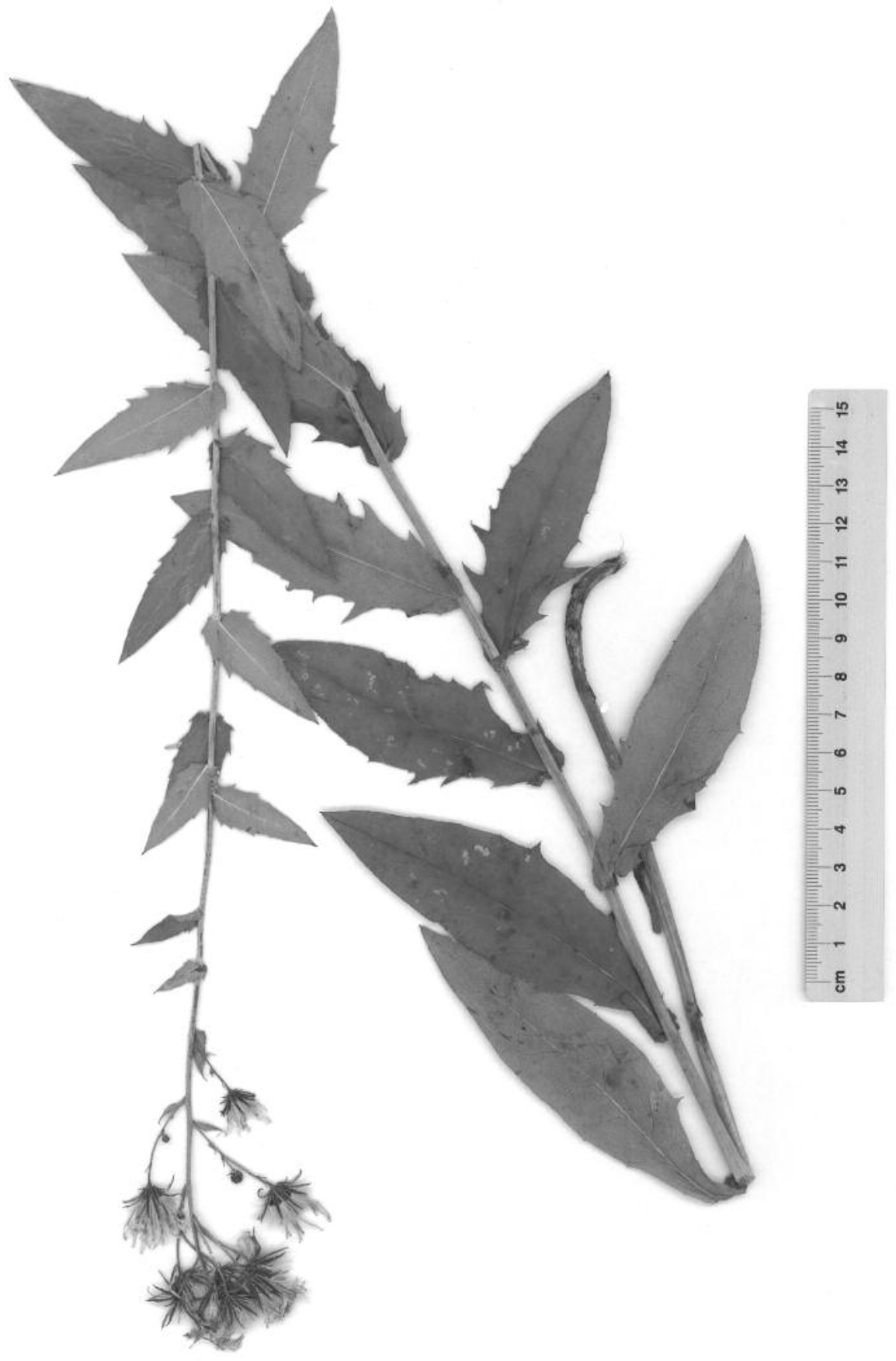

Fig. 1. Holotype of Hieracium zajacii Szeląg.

Baden-Württemberg (Schuhwerk and Lippert 1999). Based on morphological differences and considering its apomictic mode of reproduction, I decided to describe the plants from the Velká Fatra Mts as a new species.

\section{Hieracium zajacii Szeląg spec. nova (Fig. 1)}

Species nova e Hieraciorum sectione Prenanthoidea W. D. J. Koch, Hieracio lycopifolio Froel. simillima, sed involucris minoribus et densius glandulosis, caulis minus pilosus, ad basim epilosus vel parce pilosus distincta.

Aphyllopodous. Stem 70-90 cm high, robust, purplebrown and almost glabrous at the base, in the lower and middle part with numerous to subdense, pale, 1-2.5 mm long simple hairs and few to sparse stellate hairs, in the upper part (within synflorescence) with dense stellate hairs mixed with 0.6-1.0 mm long, dark-based simple hairs and
0.3-0.7 mm long, yellowish glandular hairs and numerous yellowish microglands. Basal leaves withered at anthesis. Cauline leaves 20-30, gradually reduced upwards, oblanceolate to lanceolate, acute at apex; the lower cauline leaves finely denticulate or \pm entire, $12-15 \mathrm{~cm}$ long and 2-3 cm wide, tapered to a long, winged petiole, on both surfaces with scattered, pale $0.8-1.5 \mathrm{~mm}$ long simple hairs, on the margins and along the midrib with numerous, pale, $0.8-1.5 \mathrm{~mm}$ long simple hairs; the middle and upper cauline leaves sessile and semi-amplexicaul, sharply and conspicuously dentate, on both surfaces with sparse, pale 0.8-1.5 mm long simple hairs and sparse stellate hairs, on the margins and along the midrib on the lower surface with numerous pale, 0.8-1.5 mm long simple hairs and few yellow-brown microglands. Synflorescence with 15-30 erect capitula. Synflorescence branches 6-12, up to $10 \mathrm{~cm}$ long, confined to upper 
part of stem, with 2-4 capitula. Acladium up to $2 \mathrm{~cm}$ long. Peduncles green, thin, with numerous to subdense stellate hairs and numerous yellowish $0.3-0.7 \mathrm{~mm}$ long glandular hairs, without simple hairs. Bracteoles 2-4, lanceolate, dark green with numerous stellate and glandular hairs and a tuft at the apex. Involucres cylindrical, 8-9 mm long, covered by dense indumentum. Involucral bracts lanceolate, obtuse to subacute at apex, the outer bracts dark green to blackish green, with numerous stellate hairs and dense, 0.3-0.9 mm long, yellow, black-based glandular hairs; the inner bracts with pale green margins and sparse indumentum. Ligules yellow with numerous simple hairs at apex. Styles yellowish with blackish scales. Achenes stramineous, 3.9-4.0 $\mathrm{mm}$ long. Pappus pale-grey. Pollen grains few, spherical and of heterogeneous size. Flowering: August.

Holotypus: Slovakia, Western Carpathians, Velká Fatra Mts, Velká Ramžiná valley, 900 m a.s.1., 4851'53”N, 1904'16”E, 2. Aug. 2008, Z. Szelag (KRA) (Isotypes: KRAM, Herb. Hierac. Z. Szeląg).

Paratypi: Slovakia, Western Carpathians, Velká Fatra Mts, Vel'ká Ramžiná valley, $900 \mathrm{~m}$ a.s.1., 4851'53'N, $19^{\circ} 04^{\prime} 16^{\prime \prime} \mathrm{E}$, plants raised from the seeds collected on 2 . Aug. 2008 and cultivated in the author's garden, herbarized on 28. Aug. 2009, Z. Szelag (Herb. Hierac. Z. Szeląg).

\section{Distribution and habitats}

Hieracium zajacii is endemic to the Velká Fatra Mts in Slovakia. It was found in the Vel'ká Ramžiná valley (the upper part of the Turecká Dolina valley) on the southern slope of Mt. Krížna at 880-920 m a.s.1. The population was composed of ca. 30 flowering individuals growing in a few clusters along a tourist route leading to the summit of Mt. Malá Krížna. The habitat of $H$. zajacii is anthropogenic glades in the beech forest belt on limestone. It grows in association with Astrantia major L., Calamagrostis arundinacea (L.) Roth, Centaurea mollis Waldst. et Kit., C. phrygia L., Chrysanthemum subcorymbosum Schur, Cicerbita alpina (L.) Wallr., Cirsium erisithales (Jacq.) Scop., C. eriophorum (L.) Scop., Clinopodium vulgare L., Digitalis grandiflora Mill., Eupatorium cannabinum L., Galium schultesii Vest., Geranium sylvaticum L., Heracleum sphondylium L., Hypericum maculatum Crantz, Laserpitium latifolium L., Origanum vulgare L., Rosa pendulina L., Senecio hercynicus Herborg and Stachys alpina L.

\section{Etymology}

The species epithet honours Prof. dr. hab. Adam Zając, the Director of the Institute of Botany of the Jagiellonian University in the years 1992-2008, for his noteworthy contribution to the knowledge of chorology of the Polish flora.

\section{Hieracium lycopifolium Froel. specimens examined.}

Carlsruhe [locus classicus] an lichten Waldstellen, selten, Ende Aug. 1843 A. Braun (PRC); Flora Friburgensis et regionum proxime adjacentium. In den Waldparthien des waldigen Schlossbergs. Freiburg. Baden. Standort des Alex. Braun Freiburg 24. Aug. 1877 A. Götz (PRC); Flora Friburgensis. In den Waldparthien des Schloßbergs bei Freiburg in Baden. 24. Aug. 1878 A. Götz (PRC - two sheets); C. Baenitz Herbarium Europaeum No. 5571. Fl. Badensis: Freiburg, 20. Aug. 1887 Neuberger (PRC - two sheets); Flora von Baden. Freiburg am Schlossberg, Aug. 1891 A. Schatz (PRC); Dr. C. Baenitz Herbarium Europa- eum, Flora Badeniae, Schloßberg bei Freiburg, 450 m, 1. Sep. 1899 A. Götz (PRC).

\section{DISCUSSION}

According to Zahn (1929), Hieracium lycopifolium Froel. is a hybrid derived from mountain $H$. prenanthoides Vill. and lowland H. sabaudum L., which originated in the last glacial period when the lowering of the mountain vegetation belts made contact between the parent species possible. However Gottschlich (1996a) does not regard H. lycopifolium as a hybrid, but rather as an independent species of $H$. sect. Prenanthoidea W. D. J. Koch that occurs in the lower parts of the Western Alps and their foreland. In Schwabien (Schwäbischen Alb), H. lycopifolium grows in relic, thermophilous forests of Quercetalia pubescenti-petraeae (Gottschlich 1996a, b).

The discovery of $H$. zajacii in the Western Carpathians casts new light onto the problem of the origin of H. lycopifolium taxa. Due to considerable disjunction dividing the Western Alps and Western Carpathians and the lack of intermediate stations of $H$. lycopifolium in the Eastern Alps, it seems hardly possible that $H$. zajacii migrated to the present site all the way from the Western Alps. The small range occupied by $H$. zajacii in the Vel'ká Ramžiná valley, as well as anthropogenic character of its habitat suggest, that it may be a local hybrid between $H$. prenanthoides and (presumably) $H$. sabaudum. Because of the moderate elevation of the Velká Fatra Mts, the vertical size of the montane forest belt is small. Moreover, multi-century pastoral activity in the Western Carpathians has resulted in lowering of the treeline and elevating the vertical ranges of many lowland plants. Anthropogenic glades in the upper part of the Turecká Dolina valley, created by cutting down the beech forest, are places at which mountain and lowland species grow side by side.

Hieracium lycopifolium s. lat. comprises 12 taxa that Zahn conservatively kept at subspecies rank (Zahn 1938; Gottschlich 2009). The taxonomic position of some of the subspecies is highly controversial, especially where multiple taxa are recorded from the same stations, as Salvan in Wallis (Switzerland) from where Zahn (1938) enumerated seven subspecies. Obviously, the H. lycopifolium agg. demands a taxonomic revision using modern methods. From the practical point of view, the division of the aggregate into three initial groups seems useful: (1) taxa morphologically intermediate between $H$. prenanthoides and $H$. sabaudum (grex lycopifolium), (2) taxa morphologically closer to $H$. prenanthoides (grex bifrons) and (3) taxa morphologically closer to $H$. sabaudum (grex pseudovallesianum). Hieracium zajacii and $H$. lycopifolium s. str. belong to the first of these groups.

\section{ACKNOWLEDGMENTS}

I am grateful to Dr. Tim Rich (Cardiff) for valuable remarks on the manuscript and English correction and to Dr. Tomasz Ilnicki (Kraków) for karyological analysis. I thank the Curator of the PRC for the loan of herbarium material. This study was supported by the Polish Ministry of Science and Higher Education, grant no. NN303089734. 


\section{LITERATURE CITED}

GOTTSCHLICH G. 1996a. Hieracium lycopifolium Froelich, eine neue reliktäre Hieracium-Art auf der Schwäbischen Alb. Jahreshefte der Gesellschaft für Naturkunde in Württemberg 152: $167-174$.

GOTTSCHLICH G. 1996b. Hieracium. In: Sebald O., Seybold S., Philippi G. Wörz A. (eds), Die Farn- und Blütenpflanzen Baden-Württembergs Bd. 6, 393-535. E. Ulmer, Stuttgart.

GOTTSCHLICH G. 2009. Die Gattung Hieracium (Compositae) in der Region Abruzzen (Italien) Stapfia 89: 1-328.

MRÁZ P., SZELĄG Z. 2004. Chromosome numbers and reproductive systems in selected species of the genera Hieracium L. and Pilosella Hill (Asteraceae) from Romania. Ann. Bot. Fennici 41: 405-414.

RONIKIER M., SZELĄG Z. 2008. Differentiation among disjunct populations of agamospermous species of Hieracium section Cernua (Asteraceae) in Central European subalpine habitats. Bot. J. Linn. Soc. 158: 93-105.
SCHUHWERK F., LIPPERT W. 1999. Chromosomenzahlen von Hieracium (Compositae, Lactucaceae) Teil 3. Sendtnera 6: 197-214.

SZELĄG Z. 2004. Taxonomic and nomenclatural notes on Hieracium silesiacum (Asteraceae). Pol. Bot. J. 49: 15-20.

SZELĄG Z. 2006a. Hieracium vierhapperi (Asteraceae) a new species to the Carpathians, with some remarks on its origin. Biologia (Bratislava) 61: 19-24.

SZELĄG Z. 2006b. Taxonomic revision of Hieracium sect. Cernua (Asteraceae) in the Carpathians, Sudetes and Alps. Pol. Bot. J. 51: 97-153.

SZELĄG Z., ILNICKI T., NIKETIĆ M., TOMOVIĆ G. 2007. Diploid chromosome numbers in five Hieracium species from Serbia and Montenegro. Acta Biol. Cracov. Ser. Bot. 49: 119-121.

ZAHN K.H. 1929. Hieracium L. In: Hegi G. (ed.), Illustrierte Flora von Mitteleuropa Bd. 6(2), 1182-1351. J. F. Lehmanns, München.

ZAHN K.H. 1938. Hieracium L. In: Graebner P. fil. (ed.), Synopsis der mitteleuropäischen Flora Bd. 12(3), 1-708. Borntraeger, Berlin. 